\title{
Dynamic Behaviors of Redox Mediators within the Hydrophobic Layers as an Important Factor for Effective Microbial Fuel Cell Operation
}

\author{
Youngjin Choi, Namjoon Kim, Sunghyun Kim, ${ }^{* * *}$ and Seunho Jung

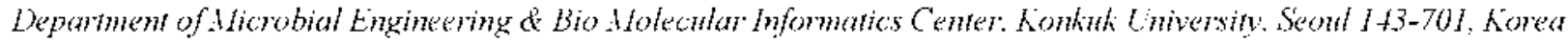

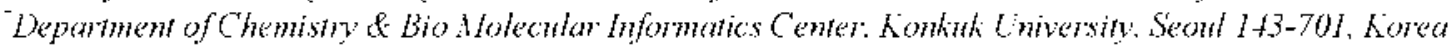 \\ Received December 16,2002
}

\begin{abstract}
In a mediator-aided microbial fuel cell, the cheree ol a proper mediator is one of the most important factors lor the development of a beter fus cell system as it transfers electrons from bacteria to the electrode. The sectrochenical behaviors within the lipid lay er of two reprexentative mediators, thionin and saliranine $O$ both of which exhibit reversible sectron transter reations, were compared with the luel cell elficiency. Thionin was found to be much more eflective than salranine o though it has lower negative formal potential. Cyelic voltammetric and 11uorescence spectroseopic analyses indicatod that hoth mediators casily penetraled the lipid lay w to pick up the electrons produced inside bacteria. While thionin could pass through the lipid layer, the gradual accumulation of saltranine o was observed within the layer. This restrieted dynamie behavior of salianine o led to the poor luel cell operation despite its good negative lomal polential.
\end{abstract}

Key Words : Microbial fuel cell. Redox mediator, Cyclic voltammetry, Phospholipid, rluorescence

\section{Introduction}

Many kinds of chemical fucl cells lave becn dereloped to resolve future energy problems. ${ }^{\text {' }}$ Microbial fucl colls have also been devised as a response to these problems. in which the anodic reaction was replaced by living microorganisms. ${ }^{-5}$ Electrons generated from the catabolic action of microorganisuns can be transferred through the cell membrane to the anode. Since the microbial cell membrane generally functions as a barrier to the electron transfer. a proper incdiator is necded to increase the fucl cell efliciency, ${ }^{6:}$ Although various microorganism-mediator combinations lave becn proposed. $^{\text {-30 }}$ their molecular mechanisms have not becn clearly understood. It was belicied that the role of the mediator was just belicred to transfer electrons produced from the oxidation of substrates to the anode. with the mediator itself undergoing a redox reacion, ${ }^{\text {d. }}$ This paper reports results of clectrochemical and fluorescence spectrometric analyses on the dy namic belavior of mediators within the lipid layers. Safranine $O$ and thionin were compared based on their penctration property in the phosplatidylcholine (PC) layers. and this procedure has becn used as a model system for the study of a mediator-membrane interaction. Safranine $\mathrm{O}$ is a well-known phenazine redox dye and its redox potential is negative enough to produce an appreciable cell polential (Table 1). Howerer. its efficiency as an clcctron (ransfer mediator in microbial fucl cells was known to be very fecble. "The results obtained in this paper cxplaincd why safranine of functioned poorly within a microbial fucl cell in spitc of their high negative redox polential.

"Co-Comesponding authors: Sunghyun Kim (Phone: +82-2-4503378: lax: +82-2-456-2744: L-mail: skim 100i( konkukac.kr). Scunho Iung (Phone: $+82-2-450-3520$ : Fax: $+82-2-452-3611$ : L-mail: shing (akjonkuk ac.kr)

\section{Experimental Section}

Chemicals. L- $\alpha$-phosphatidy lcholine (PC). safmanine $\mathrm{O}$ and 1.6-diphenyl-1.3.5-hexatricne (DPH) were purchased from Sigma (St. Louis. U.S.A.) and thionin from Janssen Chimica (Gecl. Belgium). All reagents were used withoul further purfication. Other reagents were of the best quality available.

Preparation of Microorganisms. Protens bulgoris (ATCC 6059) and Escherichic coli (ATCC 25922) were oblaincd from the culture collcction of KCCM (Korcan Culture Center of Microorganisms) and kept on a nutricnt agar platc at $4{ }^{\circ} \mathrm{C}$. Experimental cultures were grown acrobically at 37 ${ }^{\circ} \mathrm{C}$ in a nutricnt brotl containing $3 \mathrm{~g}$ of becf cxtracl and $5 \mathrm{~g}$ of peptone per liter. Each cell was harvesicd by centrifuging at $3.000 \times \mathrm{g}$ for $5 \mathrm{~min}$ and washed wice with $50 \mathrm{mM}$ phosplate buffer solution $(\mathrm{pH} 7,0$ ). The washed microorganisms were resuspended in the phosplate buffer to give 20 ing (dry w1) $\mathrm{mL}^{1}$ for the experiment.

Fuel Cell Assembly and Current Output Measurements.

Table 1. Redos mediators, their structural formulac and romal poluntials $\left(L^{\circ}\right)$

Redox mediator

* Data taken from Figure $2 . F^{*}-\left(F_{\mathrm{j} w} \cdot F_{\mathrm{p}^{\mathrm{x}}}\right){ }^{2}$ 
Each cell unit composed of anode and cathode compartments (internal dimensions $45 \times 45 \times 15 \mathrm{~mm}$ ) and separated by a cation exchange membrane (Nafion. Aldrich). A reticulated vitreous carbon (RVC, $30 \times 30 \times 12 \mathrm{~mm}$ ) plate was used as an anode. Microorganism and mediators were added to the anodic compartment, and a $50 \mathrm{mM}$ phosphate solution ( $\mathrm{pH} 7.0$ ) was used as an anolyte. A platinum plate $(30 \times 30 \times 0.5 \mathrm{~mm})$ was used as cathode material. and $0.1 \mathrm{M}$ ferricyanide solution as a catholyte. ${ }^{1]}$ During the experiments. nitrogen was made to flow through the cell compartments for oxygen removal. Operation temperature was maintained at a constant value of $37^{\circ} \mathrm{C}$ in a water bath. The cell discharge was performed by the $560-\Omega$ extemal resistor between an anode and a cathode. The discharge curve was recorded only after the open circuit voltage was stabilized with nitrogen gas flowing through the cell. The cell voltage over time was then recorded with a personal computer equipped with an analogue-to-digital board (Computer Boards. Mansfield. MA. USA). An output current was simply calculated using the olumic law, $I=I^{\circ} \cdot c_{\text {cul }} / R_{\text {loval }}$. When the cell voltage dropped to the background level, the cell was charged with a carbon source ( $1 \mu \mathrm{mol}$ of glucose) for another discharge measurement. Generally: the cell voltage increased rapidly upon injection of the glucose and reached a plateau level as long as there were enough carbon sources to be consumed by microorganisms. and then the cell voltage began to gradually decrease. The electricity produced was calculated by integrating the discharge curve with time. ()$=$ $\int l d t$.

Electrochemical Analysis. PC was diluted to $2.1 \mathrm{mg} / \mathrm{mL}$ with chloroform for the cyclic voltammetric measurements. $0.5 \mathrm{mM}$ solutions of mediators were prepared from $0.1 \mathrm{M}$ phosphate buffer ( $\mathrm{pH} 7.0$ ) using $18 \mathrm{MS}^{-1} \mathrm{~cm}^{-1}$ deionized water. The cast layer of PC was formed by applying $3.0 \mu \mathrm{L}$ of PC solution onto the glassy carbon (GC) electrode and allowing it to dry. Then the prepared electrode was immediately transferred into each deaerated mediator solution. The comentional three-electrode system (AUTOLAB PGSTAT30) was used to record voltammograms. ${ }^{2}$ A platinum wire and an $\mathrm{Ag}|\mathrm{AgCl}| \mathrm{KCl}_{\text {sial }}$ electrode were used as the counter and the reference electrode, respectively. GC was subjected to polishing with $0.05 \mu \mathrm{m}$ alumina until there was a mirror finish. and subjected to ultrasonication for $30 \mathrm{sec}$ every time new sets of data were acquired. All the experiments were done under room temperature and atmospheric pressure.

Sample Preparation for Fluorescence Measurements. DPH incorporated unilamellar vesicles formed by extrusion. ${ }^{19}$ $10 \mathrm{mg}$ of PC and DPH (molar ratio 500:1) were dissolved in chloroform to facilitate mixing. and uniform probe distribution. The chloroform was then evaporated to form a thick film. $1 \%$ of $\alpha$-tocopherol was added to prevent lipid oxidation. Then. the lipid film was dispersed with $50 \mathrm{mM}$ tris- $\mathrm{HCl}$ buffer $(\mathrm{pH} 7.3)$ and extmided through the $100 \mathrm{~mm}$ membrane filter at $50^{\circ} \mathrm{C}$. Particle size of the vesicles was measured by a ZetaPALS particle size analyzer (PSA) in order to confirm the precise vesicle formation. The resulting vesicles were unilamellar. with an average diameter of approximately $1+0 \mathrm{~nm}$

Fluorescence Quenching Measurements. Fluorescence emission spectra were measured in a $1 \mathrm{~cm}$ path length quartz cuvette using a Hitachi F-2000 spectrofluorimeter at room temperature. The excitation and emission wavelengths were set at $35.5 \mathrm{~nm}$ and $432 \mathrm{~nm}$. respectively. For the quenclung process. safranine $\mathrm{O}$ and thionin were used as fluorescence quenchers. After the addition of a quencher into DPHincorporated vesicles. a decrease in the fluorescence signal was recorded $F_{\mathrm{w}} / F$. the ratio of the DPH fluorescence intensity in the absence $\left(F_{i}\right)$ to that in the presence $(F)$ of the quencher. was deternined.

\section{Results and Discussion}

Figure l shows typical current-time responses in the microbial fuel cell after the addition of glucose as a carbon source. $P$. vulgaris and $E$. coli were used as model bacteria in this fuel cell system. Thionin exhibited a nomal discharge behavior in the fuel cell containing both bacteria. while safranine $O$ gave a very low current output in the same
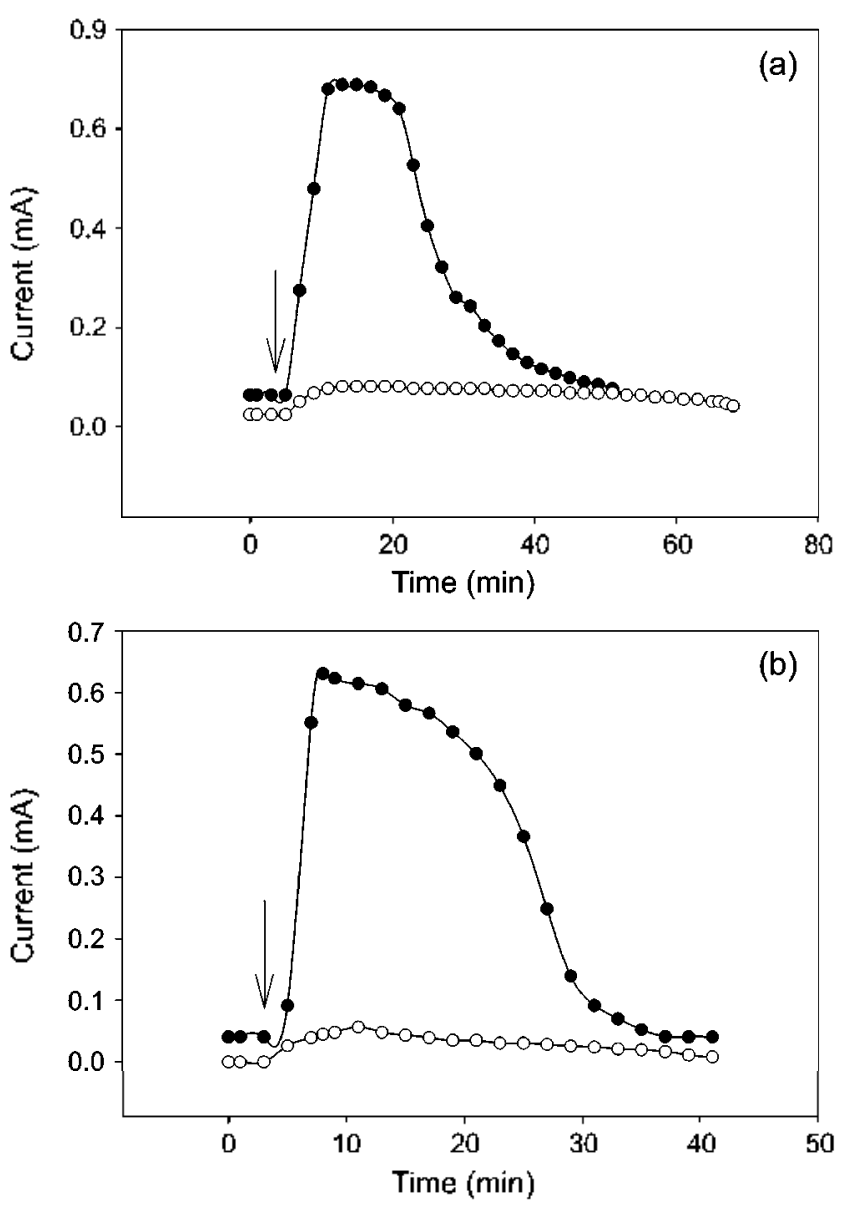

Figure 1. Variation of current oulput with time through the 560- $\Omega$ exteral load for tilel cells containing (a) $R$. vulganis and (b) $E$. coli with satranime $O(\because)$ and thionin $(\bullet)$ as the electron transter mediator. Organism concentration: $1 \mathrm{mg}$ (dry w $\mathrm{mL}^{-1}: 1 \mu \mathrm{mol}$ of mediator and $1 \mu \mathrm{mol}$ of glucose were added. Addition of glucose is marked by the arrows 

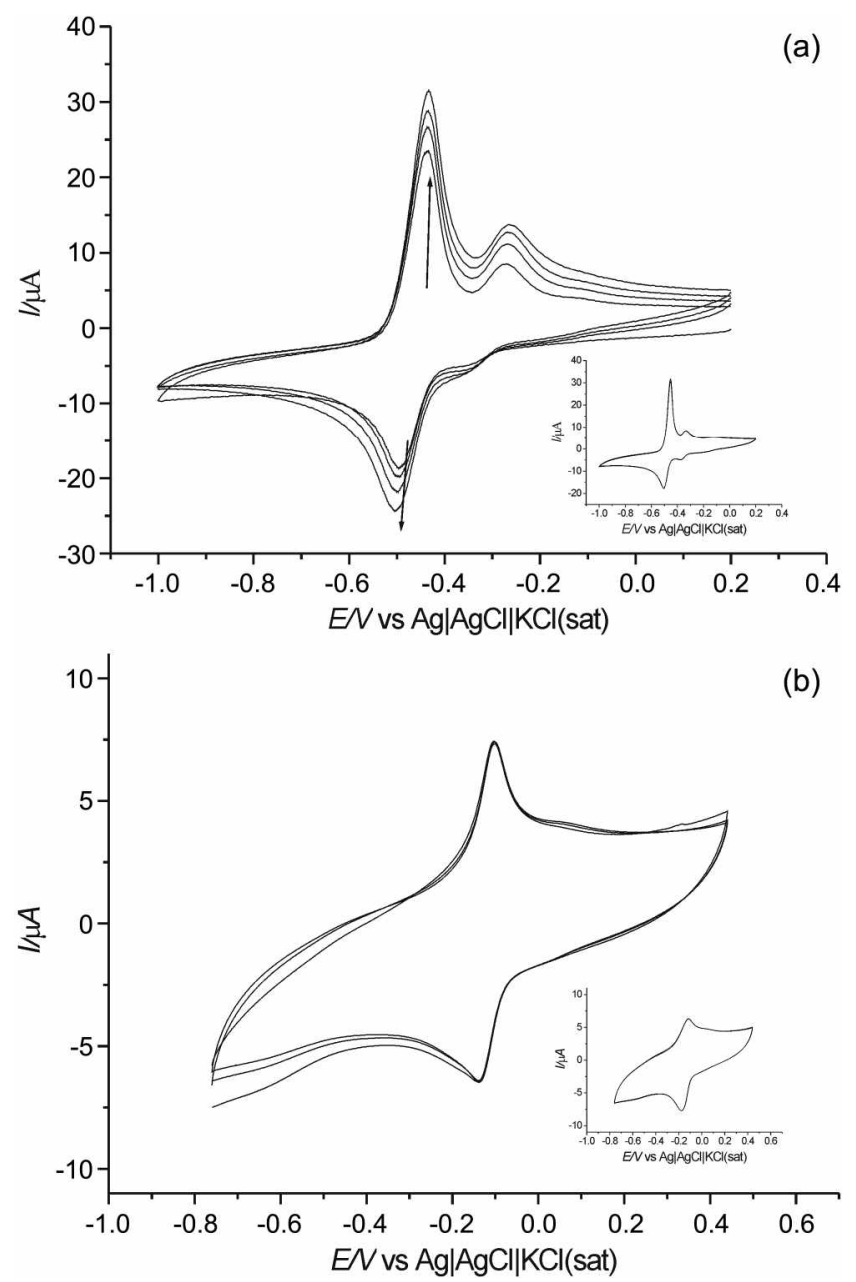

Figure 2. Cyclic voltammograms of salranine $O$ (a) and thionin (b) in the PC Iilm at pII 7.0 solution. Scan rate: $100 \mathrm{mV} \cdot \mathrm{s}$. Llactrode atea: $0.071 \mathrm{~cm}^{2}$. Inset shows the voltammogram on the bare electrode.

operational conditions. These results show that the choice of a proper mediator is a decisive factor in better fuel cell operation. Figure 2 shows cyclic voltammograms of $0.5 \mathrm{mM}$ mediators inside a PC film. $3.0 \mu \mathrm{L}$ of $\mathrm{PC} /$ chloroform solution was applied onto the GC surface and the solvent allowed to evaporate. Compared with bare electrodes (inset). the overall voltammetric shapes remained the same even in the presence of a PC layer which showed a well-defined redox peak. In the case of safranine $O$. the gradual increase of current, which eventually reached a steady-state value after many cycling. was observed upon the repeated potential crcling. indicating the accumulation of safranine $\mathrm{O}$ in the PC laver. But thionin is not readily accumulated in the PC layer since there is a slight increase in current. For an efficient fuel cell operation both the oxidized and reduced forms of a mediator should freely penetrate the bacterial cell membrane. In the case of safranine $O$. the oxidized form can go inside the membrane to take up the electrons produced from the oxidation of the substrate. but once reduced inside the cell membrane it resides there. not being able to deliver the electrons to the anode. making the fuel cell efficiency

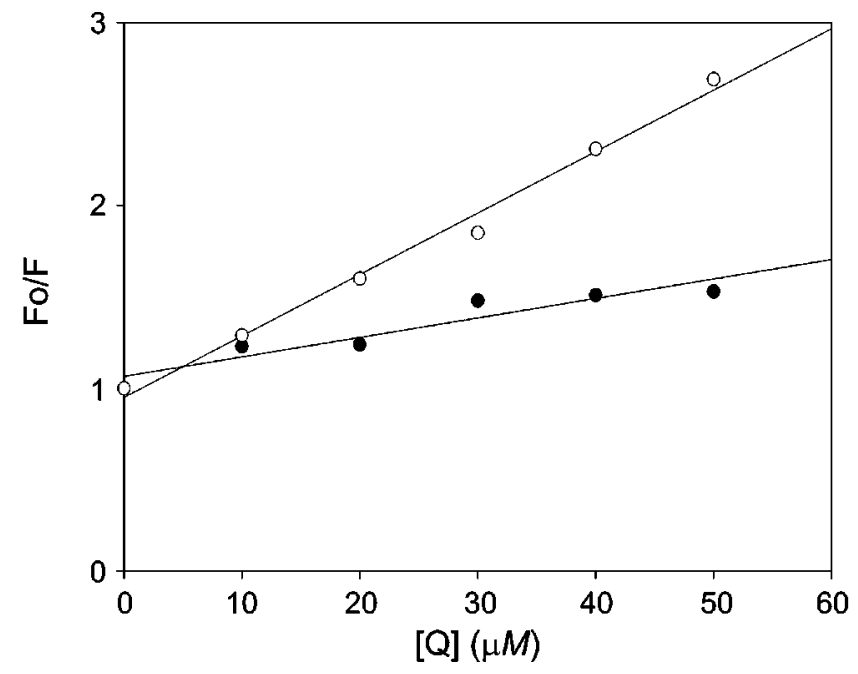

Figure 3. Plot of $/{ }^{\prime} / l^{\circ} v,\lfloor\mathrm{Q}\rfloor$ according to Stens-Volmer equation in achous modium with solramine $O(\cdots)$ and thionin (•). Calculated Stern-Volmer quenching constants ( $\mathrm{K}_{\text {s. }}$ ) of mediators are $0.03 .36 \mathrm{M}^{-1}$ tor satranine $\mathrm{O}$ and $0.0107 \mathrm{M}^{-1}$ tor thionin.

low. ${ }^{1.3}$ The reduced form of thionin. however can carry the electrons to the anode, passing through the cell membrane.

The penetration property of mediators was also confirmed by the fluorescence quenching study. Fluorescence is a very sensitive technique for understanding the dynamics of fluorescent molecules within a lipid bilarer which conposed of amphiphilic molecules such as phospholipids. lnfomation for the location of fluorescence molecules within lipid vesicles can be acquired using quencher molecules because quenching is effective when their distances are closely approached. A DPH molecule was known to be located deep within the lipid bilayers and their fluorescence is enhanced in nonpolar enviroiments such as lipid membranes. ${ }^{1+15^{5}}$ Since fluorescence emissions are sensitive to circumstances. they are easily quenched by various fluorescence quenchers such as iodide or molecular oxtgen. ${ }^{16}$ The degree of quenching is irwersely proportional to the sixth power of molecular distance. ${ }^{1^{-}}$and therefore we can easily examine the dynamic interaction or location of molecules within a lipid layer. The fluorescence quenching of the DPH enission in vesicles with safmuine $O$ and thionin was shown in Figure 3. DPH was used as a fluorescence probe. and mediators as quenchers. The Stern-Volmer quenching constant $\mathrm{K}_{\mathrm{sV}}$ was calculated by plotting $F_{0} / F$ against $Q$ from the equation ${ }^{1+, 1 \%}$ :

$$
F, / F=\mathrm{K}_{S \mathrm{Y}} \cdot[\mathrm{Q}]+1
$$

where $F_{0}$ is DPH fluorescence intensities in the absence of a quencher. $F$ is the intensities in the presence of the quencher. and $Q$ is the concentration of the quencher. A larger $K_{S T}$. means strong quenching of DPH. Since the slope of safranine $\mathrm{O}$ is higher than thionin. it can be concluded that DPH was heavily quenched by safranine $O$. Because the quenching process takes place only at a close range. most safranine $\mathrm{O}$ molecules should be found in lipid vesicles or found surviving longer in the DPH located in the lipid layers. 
However, thionin did not seem to be fixed within the lipid layers according to the cyclic voltammetric results. The safranine molecule has more lipophilic aromatic moieties. and known to be accumulated by a stacking mechanism on the inner surface of the lipid membrane. ${ }^{19}$ The effective mediator in a microbial fuel cell system should be freely and reversibly passed to the lipid layers, yet saframine $O$ accumulated in lipid layers and could not easily escape from there. That is why safranine $O$ was rarely utilized as an electron transfer mediator within a nicrobial fuel cell in spite of its very negative redox potential. These facts could be explained by their accumulative property in the lipid membranes.

In conclusion, dynamic behaviors as well as electrochemical properties were important factors necessary for an efficient mediator in a microbial fuel cell system. Cyclic voltammetric and fluorescence spectroscopic analy ses indicated that both mediators could penetrate lipid layers for the electron transfer. but the gradual accumulation of safranime $O$ was observed within the lipid layers whereas thionin was effectively passing through. This restricted dy namic beharior of safranine $\mathrm{O}$ in lipid layers suggested it would be inefficient in a microbial fuel cell system despite its good negative redox potential. These findings will be applied in the further development redox mediators for an efficient microbial fuel cell system.

Acknow ledgment. This research was supported by grant No. KOSEF 2000-2-211-004-3 from the Basic Research Program of the Korea Science \& Engineering Foundation. SDG.

\section{References}

1. Kordesch. K.: Simander. G. Fut Ch/ls and Their Applications. VCH: New York. 1996.

2. Akiba. T.: Bemento. H. P'.: Stirling. J. L.: Jankaka. K Biodectmot. Lett 1987. 9,611.

3. Nllen, R. M.: Bennetto, H. P. Appl Biochem. Biotecinol. 1993. 3940.27

4. Choi. Y.: Song. S.: Jung. S.: Kim. S. J. Microbiol. Biotechol. 2001. 11.863.

5. Kim. N.: Choi. Y.: Jung. S.: Kim. S. Biotechol. Bionge 2000. 70 . 109.

6. Kim. H. I.: IIyutn. M. S.: Chatng. I. S.: Kim, B. II. J. Whorohiol. Biotechind 1999, 9. 365

7. Roller. S. D.: Bennetto. H. P:: Delaney. G. M.: Mason. I. R.: Stirling. J. L.: Thurston. C. F, J. Chem. Tech. Biofechnot 1984. $3+B .3$.

8. Bennetto, H. P.: Dew: M. F.: Stirling. I. I.: Tatraka. K. ('hem. Indust. 1981. 7,776.

9. Bennetto, II. P.: Stirling. J. I. (hem. Indhst 1985. 21.695.

10. Delaney. G. M.: Bemnetlo. H. P': Mason. I. R.: Roller. S. D.: Stirling. J. L.: Thurston. C. F, J. Chem. Tech. Biotechol. 1984. $3+B .13$.

11. Kaiser, R. D.: London. F. Biochemistm 1998, 37. 8180

12. I.angner, M.: Hui. S. W. (Tem Phys Lipids 1991.60, 127.

13. Wu, P.; Brand. I... Inal Biochem. 1994. 2/8, 1.

14. Deumie. M.: Baraka. M. Ė: Quinones. E. J. Photochem. Photobiol t 1995. 87. 105.

15. Kim. N.: Choi. Y.: Jung. S.: Kim. S. Bull Norem Chem Soc. 2000. 21.44

16. Won. M. S.: Shim, Y. B.: Park. S. M. Bull. Romean Chem. Soc. 1992, 13. 680 .

17. Kim. S.: Jung. S. Bull. Konem Chem. Soc: 1997. 18. 1318.

18. Blall. E.: Sawler. W. H. Biochim. Biophys fcto 1985. 822.43.

19. Bally: M. B.: Hope. M. I.: Van Echleld. C. I. A.: Cullis. P. R. Biochim. Biophls icta 1985, 812.66. 